\title{
THE STRATEGY FOR IMPROVEMENT OF ENTING GETI QUALITY IN PRODUCTION PROCESS WITH FUZZY ANALYTICAL HIERARCHY PROCESS IN BLITAR REGENCY, EAST JAVA
}

\author{
Siti Asmaul Mustaniroh ${ }^{* 1}$, Ninda Ayu Puspitasari*), and Jaya Mahar Maligan*) \\ *) Faculty of Agricultural Technology, Universitas Brawijaya (UB) \\ Jl. Veteran, Malang 65145
}

\begin{abstract}
SMEs of peanut snack "Enting geti" in Blitar Regency is divided into several clusters based on performance and product quality. The center of Enting geti SMEs is in Rejowinangun village, Blitar Regency, East Java. The main problem in SMEs is the diversity of production process between SMEs and unstandardized formulas such as inconsistencies in quality. This study aimed at determining the best formula of Enting geti based on the Indonesian National Standard (SNI) and determining the quality improvement strategy of production process. This research used 2 methods of the consumer acceptance test (organoleptic test) analyzed with the effectiveness Index and laboratory test with Multiple Attribute. The improved production process was on caramelization process and reduction of wijen composition. The treatments used were the cooking temperature of $75 \pm 2^{\circ} \mathrm{C}$ and $85 \pm 2^{\circ} \mathrm{C}$. The results based on acceptance test and laboratory test showed that the second treatment (temperature $85 \pm 2^{\circ} \mathrm{C}$ with $10 \%$ wijen reduction) was the best treatment. The priority of determining the strategy with Fuzzy Analytical Hierarchy Process found that the best strategy in the production process variable with an alternative strategy is to establish a partnership that can be done by building cooperation with several fixed suppliers and by improving the flow of information.
\end{abstract}

Keywords: consumer acceptance test, Enting geti, laboratory test, quality of improvement, production

\begin{abstract}
Abstrak: UKM produksi makanan camilan dari kacang, yaitu Enting geti di Kabupaten Blitar terbagi menjadi beberapa klaster dengan klasifikasi berdasarkan kinerja dan kualitas produk. Sentra UKM Enting geti berada di Desa Rejowinangun. Permasalahan utama pada UKM yakni keberagaman proses produksi antar UKM dengan formula tidak standar sehingga menyebabkan inkonsistensi mutu. Tujuan penelitian adalah untuk menentukan formula terbaik enting geti berdasarkan Standar Nasional Indonesia (SNI) dan menentukan strategi perbaikan kualitas proses produksi. Penelitian menggunakan 2 metode yakni uji penerimaan konsumen (uji organoleptik) dengan metode Indeks Efektivitas dan uji laboratorium dengan Multiple Attribute. Perbaikan proses produksi dilakukan pada proses karamelisasi dan pengurangan komposisi wijen. Perlakuan yang digunakan meliputi suhu pemasakan yakni $75 \pm 2^{\circ} \mathrm{C}$ dan $85 \pm 2^{\circ} \mathrm{C}$. Hasil penelitian berdasarkan uji penerimaan konsumen dan uji laboratorium,menunjukkan bahwa perlakuan kedua (suhu $85 \pm 2^{\circ} \mathrm{C}$ dengan pengurangan wijen 10\%) merupakan perlakuan terbaik. Prioritas penentuan startegi dengan Fuzzy Analytical Hierarchy Process diperoleh bahwa strategi terbaik pada variabel proses produksi dengan alternatif strategi menjalin kemitraan yang dapat dilakukan dengan membangun kerjasama pada beberapa pemasok tetap dan perbaikan aliran informasi.
\end{abstract}

Kata kunci: penerimaan konsumen, Enting geti, uji laboratorium, perbaikan kualitas, produksi

\footnotetext{
${ }^{1}$ Corresponding author:

Email: asmaul_m@yahoo.com
} 


\section{INTRODUCTION}

The agroindustry which influences the economic growth and utilization of natural resources in Indonesia is the Small and Medium Enterprise (SMEs). One of the regions that have developed their natural resources is the great potential of the Kademangan sub-district (the coastal part of Blitar district) of Blitar Regency. The local agricultural commodity developed is peanuts. The local food industry has economic potential as well as social potential for the economic value of the commodity and an increase in the community income. The role of the local food industry is shown a the large number of local food industries in each region. This means that the local food industry does not only need to be preserved but also needs to be continuously fostered and developed by the existing local potential by continuing to improve its competitiveness. The Food and Beverage Industry will affect the increase in the community income. There are several types of food industries, and the traditional or small-scale food industry is one of the economic supports for the community. One way to develop local food is through industrialization. SME performance is said to be good if the production capacity is produced with market demand i.e. by marketing products strategically because the chosen marketing strategy will be able to penetrate the market and increase business competitiveness (Wibowo et al. 2015). Ofafa (2013) states that broad market access is able to strengthen sustainable business competitiveness where SME entrepreneurs must obtain information and communication technology competency levels (Hadiati, 2016). The most widely processed peanuts in Blitar Regency is Enting geti, a type of snack food which is derived from peanuts, similar to a combination of both (Yuyun, 2010). In this study, the SMEs used as many as 6 SMEs (the cluster of Enting geti) including Kuda Terbang, Wina Puri, Mas Puri, Sumber Rejeki, Kapal Layar, and Rita Puri Asli. The division of this cluster is based on the performance of the SMEs and product quality. The SMEs center of EntingGeti is located at the Rejowinangun Village, Kademangan District of Blitar Regency.

Problems that are often experienced in the production process are the diversity of processes between SMEs and unstandardized formulas, thus causing quality inconsistencies. According to Mustaniroh et al. (2017), clear production determination, the production process by incorporating the right formulation, can produce optimal quality products and can meet customer satisfaction. The product quality control is carried out by determining the $\mathrm{CP}$, which is the key point used to control the flow of products that pass through the system (Gaspersz, 2005). The CP in Enting geti production process is in the boiling process of brown sugar (caramelization). Cooking sugar in high temperatures can cause sugar, peanuts and similar to blend. Sugar without the right liquid consistency will cause product failure i.e. it cannot get sticky properly. Based on SNI, a good quality product is $3.5 \%$. Therefore, improving the quality of the product is a production process that needs to be done according to product standards, guaranteed safety and competitiveness. According to Kurniasanti et al. (2014) the alternative strategies for increasing the competitiveness of local products include market diversification, product diversification, increase in foreign cooperation, and development of the Research and Development division, development of existing markets and product types, and saving of production costs. One of the main components so that products can gain trust and attract consumers' attention is quality. Quality is everything that meets the customers' desires or needs. In order to produce quality products, information systems, management, and technology have to be implemented by the company (Evans, 2013).

Tests carried out included the consumer acceptance test (organoleptic tests) and laboratory tests. This test was carried out by the Effectiveness Index (IE) and Multiple Attribute (MA). According to (Nurani and Susilo, 2014), IE is a method used to determine the best value based on the organoleptic test results that have been carried out and proceed with a ranking process that will select alternatives that have been given (Idmayanti, 2014). The two methods will produce the best formula that will be compared to its suitability with SNI. The strategy to improve quality and quantity is very important through innovation and diversification into products which have the competitiveness (Setyadi et al. 2012). The improvement of product quality can be conducted through human resources training (Nayantakaningtyas and Daryanto, 2012) and standardized infrastructure facility (Widyastutik and Arianti, 2013).

Determination of production process improvement strategies used the Fuzzy Analytical Hierarchy Process (FAHP) method. This method has the ability to process language reasoning so that it is easy to understand and not complicated. Another level of decision-making is the level of decision making that can be accommodated (Norhikmah et al. 2013). FAHP is considered better 
in describing vague decisions than AHP (Wang and Kwai, 2011). The method is able to solve the problems experienced by SMEs, namely, the incompatibility of Enting geti product with SNI, and the best formulation of the product can be known through the IE and MA methods. A comparison with the SNI selects the best quality improvement process for the production strategy using the FAHP method. The objectives of this research were to determine the best formula of Enting geti for by adjusting it to the SNI and to determine the priority of the quality improvement process for the production process using the FAHP method.

\section{METHODS}

The study was conducted at the Enting geti SMEs cluster located in Rejowinangun Village, Kademangan District, Blitar Regency, East Java. Data processing and analysis were carried out at the Agroindustry Management Laboratory, Food Quality and Safety Testing Laboratory in Faculty of Agricultural Technology and Biochemistry Laboratory in Faculty of Mathematics and Natural Science Univesitas Brawijaya from February 2018 to June 2018. The parameters used in the organoleptic test included color, aroma, taste, appearance and texture, while those in laboratory tests included water content, total plate count and free fatty acids. The research only reached the determination of the priority of the right strategy to improve the quality of the production process of Enting geti and did not discuss the implementation and evaluation stages of the strategy. The conceptual of framework in this study is shown in Figure 1. The stages for the framework in the study began with the evaluation on the quality of the Enting geti products from the Enting geti SMEs cluster in Blitar District with consumer acceptance and laboratory tests. The consumer acceptance test was carried out using the best treatment analysis with Effectiveness Index (IE) while the laboratory test was carried out using by the Multiple Attribute Decision Making (MADM). The best treatment results are used as a basis for improving the next formula by synergizing the Critical Control Point (CCP) in the production process and making improvements to the production process and testing the second best treatment as in the first stage, with consumer acceptance test by IE and laboratory tests by MADM. Furthermore, based on the best formula after improvements, the production process quality strategy was formulated to be implemented in the Enting geti SMEs cluster.
The objects of the research were 6 SMEs clusters that produce Enting geti products in Kademangan District, Blitar Regency, East Java. The target population was consumers who know and have consumed Enting geti from the Enting geti SME clusters. The access population was the consumers who know and have consumed Enting geti at least once in the last 3 months. The sample of 30 respondents (customer acceptance testing) chosen randomly (random sampling) met the minimum requirements of normal distribution. The respondents involved in this study were slightly trained respondents. The use of panelists is somewhat trained because it does not require panelists who have high sensitivity but only requires non-intensive training and can use students (Suradi, 2007).

The respondents were divided into several characteristics including gender, age and type of work. These characteristics are expected to be able to represent consumers as a whole. Experts for the strategies determination were chosen as many as 4 people including 2 SME practitioners, 1 person from the Department of Industry and Trade, and 1 academic from Universitas Brawijaya. Determination of expert respondents was based on criteria that respondents were able to contribute to the improvement of the quality of Enting geti. The type of data needed was obtained from a questionnaire on the owners of SMEs Enting geti and consumers. The first questionnaire was prepared to determine consumer acceptance (organoleptic test) of the product. The second questionnaire was arranged to weight FAHP in determining the strategy to improve the production process of Enting geti. The location of the Enting geti SMEs Cluster is shown in Figure 2.

The research used 2 testing methods, namely, consumer acceptance test (organoleptic test) by distributing questionnaires to 30 people (random sampling) with the requirement of knowing and at least one time consuming the Enting geti. This method was to determine the level of preferences and perceptions of consumers and was analyzed by the method of Effectiveness Index (IE). The second test was a laboratory test conducted to determine the suitability of the initial product formula with SNI and analyzed using Multiple Attribute (MA) method. Improvement of the production process was carried out in the process of caramelization and reduction of sesame composition. The treatments used included the cooking temperatures of $75^{\circ} \mathrm{C}$ and $85^{\circ} \mathrm{C}$. 


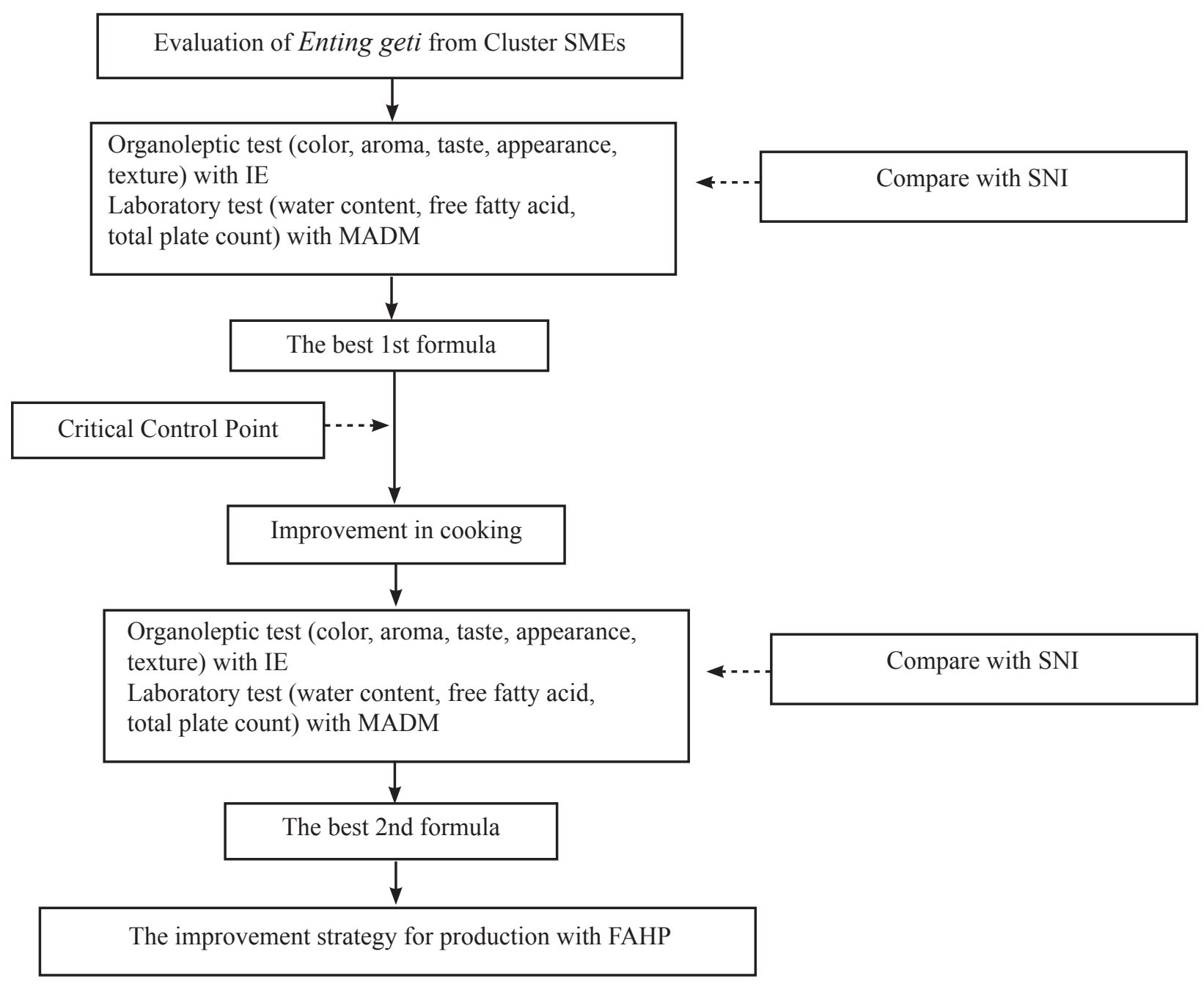

Figure 1. Research framework

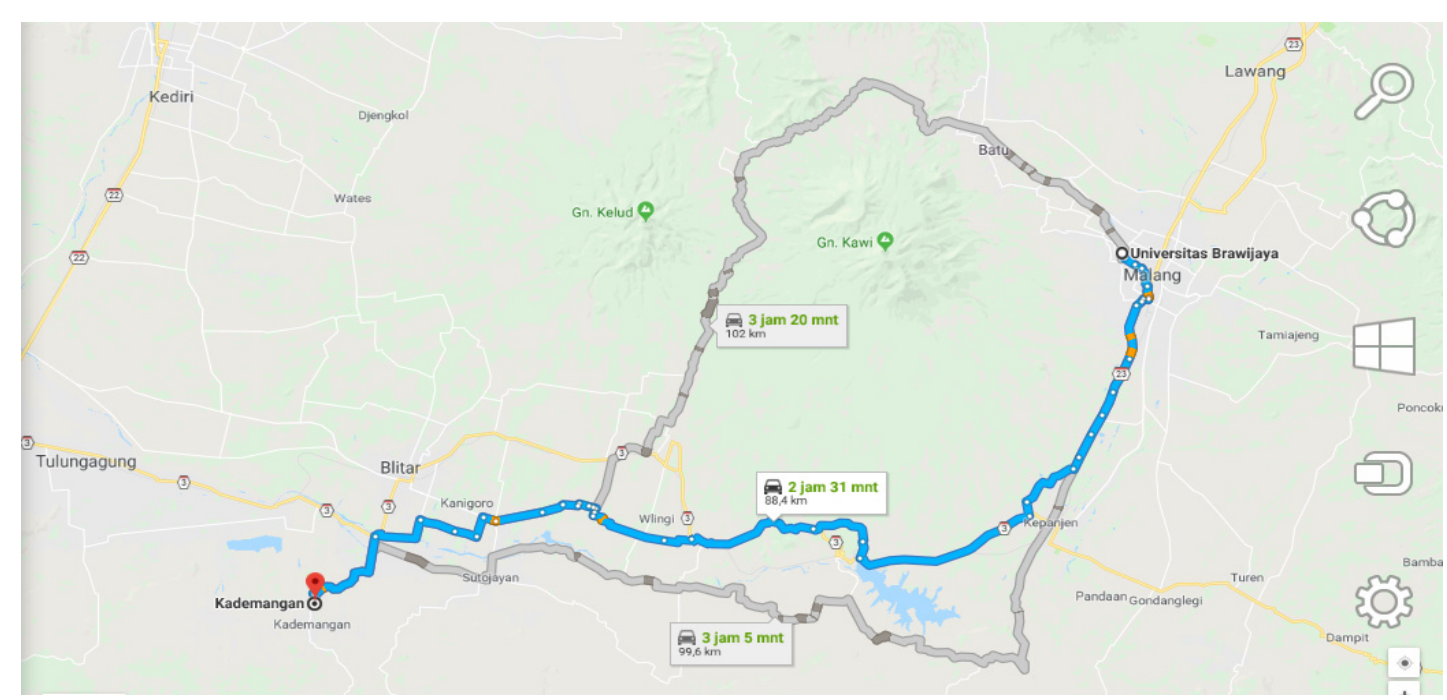

Figure 2. Position of the SMEs Enting geti Cluster Location in the District Kademangan, Blitar Regency (from Universitas Brawijaya, Malang) 
The stages of weighting analysis in the IE method (Mulyadi et al. 2014) included: 1) Grouping of physical and chemical parameters conducted separately by organoleptic parameters, 2) Each parameter was given a weight of $0-1$ in each group. The weight given was in accordance with the level of importance of each parameter in influencing consumers, represented by panelists, 3) Determination of the effectiveness value (NE) wass calculated by a formula:

$$
\mathrm{NE}=\frac{\mathrm{Np}-\mathrm{Ntj}}{\mathrm{Ntb}-\mathrm{Ntj}}
$$

where $(\mathrm{NE}=$ Value of Effectiveness; $\mathrm{Np}=$ Treatment Value; $\mathrm{Ntj}=$ Worst Treatment Value and $\mathrm{Ntb}=$ Best Treatment Value). If the greater average parameter is better, the lowest value is the worst value and the highest value is the best value, and vice versa, 4) Calculation of Product Value (NP). Product Value is obtained from the multiplication of Effectiveness Value with Weight Value, 5) Product values of all parameters in each treatment group were summed. The treatment that has the highest product value is the best treatment in the parameter group, and 6) the best treatment is chosen based on the treatment which has the highest product value for organoleptic parameters.

The selection of the best alternative using MA method (Zeleny, 1982), includes: 1) Determining the ideal value for each parameter with the ideal value which is the expected value to calculate the Degree of Density for the ideal value (minimum or maximum), 2) Calculating Distance Density by assuming all important parameters, and density distance is calculated based on the number of parameters $=1 /$ number of parameters. The results of determination of the value of Density is based on the minimum ideal value (dki), calculated based on the comparison of reality values that approach the ideal with the value of each alternative. Conversely, if the ideal value is maximum, the comparison of the ideal value of each alternative is calculated against the value of reality that is close to the ideal. The basis of the calculation for determining the density distance with the best treatment formula is chosen from an alternative that has the smallest L1, L2 and L $\infty$ values.

$$
\begin{aligned}
& \mathrm{L} 1=(\lambda, \mathrm{k})=1-\Sigma \lambda \mathrm{d}_{\mathrm{i}}^{\mathrm{k}} ; \\
& \mathrm{L} 2=(\lambda, \mathrm{k})=\left[\Sigma \lambda \mathrm{i}^{2}\left(1-\mathrm{d}^{\mathrm{k}}\right)\right]^{1 / 2} \\
& \mathrm{~L} \infty=\operatorname{maks}\left[\lambda \mathrm{i}\left(1-\mathrm{d}_{\mathrm{i}}^{\mathrm{k}}\right)\right] .
\end{aligned}
$$

Based on the data from IE and MA analysis, it is continued with the determination of the strategy using the method Fuzzy Analytical Hierarchy Process (FAHP). This method is reliable in handling ambiguous decisions of AHP (Lupo, 2013). In FAHP, and AHP pairwise comparison matrices built adaptive numbers fuzzy on fuzzy (Sahin and Young, 2017). The steps of the FAHP method (Norhikmah et al. 2013) include 1) Defining the problem, determining the desired solution, and arranging the hierarchy of problems, 2) Determining priority elements by making a pair comparison matrix, 3) Synthezing by performing 3 stages (summing the values of each matrix column, dividing each value from the column by the corresponding column to obtain the normalization of the matrix and summing the values of each row and dividing them by the number of elements/criteria to get the average value), and 4) Adjusting consistency through 4 stages (multiply each time in the first column with the priority relative to the first element/criterion, and so on, summing up each row, dividing the result of the row by the relative priority element concerned, summing the results for the number of elements, and the result is called $\lambda$ max with prior weight ratio against many elements/ criteria). Furthermore, the (CI) and the Consistency Ratio (CR) determined the boundary inconsistency. This value depends on the value of $n$, the $C R$ formula is calculated by a formula (Adnyana et al. 2016) from the comparison of $\mathrm{CI}$ and RI values to make consistency checks. If $\mathrm{CR}$ is $\geq 10 \%$, the data of research judgment must be corrected, but if the consistency ratio $(\mathrm{CI} /$ IR) is $\leq 0.1$, then the calculation results can be stated correct. The calculation steps of Fuzzy are as follows (Sriwana, 2014): 1) Determining the comparison of paired matrices between criteria with Triangular Fuzzy Number (TFN) scale, 2) Determining the value of synthesis fuzzy $(\mathrm{Si})$ to obtain relative weights for the elements of decision making, 3) Determining Vector Values (V) and Defuzzification Ordinate Values (d '), and 4) Normalizing fuzzy weight vector (W) or priority values of criteria that have been obtained.

\section{RESULTS}

\section{The Profile of Enting geti SMEs Cluster}

Enting geti SMEs cluster is located in Rejowinangun Village, Kademangan District, Blitar Regency, East Java, which is the center of the Enting geti industry. There are 15 SMEs of Enting get, but only 6 SMEs 
still actively produce and enter the cluster, including Kuda Terbang, Mas Puri, Rita Puri Asli, Wina Puri, Kapal Layar and Sumber Rejeki. The distribution of clusters is based on performance and product quality. According to Budiarto et al. (2015), a cluster means grouping in a certain area of various businesses from the same sector. The length of operation of the Enting geti SMEs included in this cluster varies, ranging from 7 to 31 years. The production capacity of each SME varies from 30 to $200 \mathrm{~kg} /$ month. This difference is due to the ability of SMEs to produce different Enting get $i$ which are influenced by the number of labor, capital and right forecasting ability of SMEs. According to Ruauw (2011), good forecasting is forecasting that approaches the reality of future conditions based on past conditions so that proper forecasting can help SMEs in determining the production of Enting geti. The selling price of Enting geti per kilogram is IDR34,000-36,000, where each SME sets a different selling price according to the sales strategy of each SME. This strategy aims to increase consumer loyalty to a certain Enting geti brand. Consumers will remain loyal if prices and quality are consistent. According to Indrayani (2004), the price is the most easily seen cost, and it becomes an important element for customers to make them loyal to one product brand.

\section{Characteristics of Respondents}

As many as 30 respondents were involved and somewhat trained respondents. The respondents or rather welltrained panelists were a group of people who know the sensory characteristics of an example that is assessed through explanation or minimal training (Suradi, 2007). The selection of respondents was based on the criteria that the respondent knew of importance and at least had consumed Enting geti at least once time. Based on the survey results, there were 22 respondents involved (73.3\%). Women tend to be consumptive in all kinds of things including snacks classified as Enting geti. According to Astuti (2013), the consumptive nature is more attached to women because they tend to buy things without thinking about their benefits and uses, and tend to buy a variety of colors and appearance. This has a psychological impact on women, which creates an interest in buying products (Stefanie, 2013). In the age characteristics, the majority of vulnerable age is 18-27 consisting of 22 respondents (73\%). Psychologically, the age group of 18-27 years have a tendency to buy a product that is higher than the older age group (Dianawati et al. 2008).

\section{Consumer Acceptance}

Determination of the first best formula was carried out by organoleptic tests including color, taste, aroma, appearance and texture. According to Molnar (2008), for the measurement of sensory (organoleptic) properties, it is important to know consumer acceptance which can be used as sensory evaluation. The next step was to analyze using the IE method. Determination of the results of IE analysis was based on the highest average product value (Mulyadi et al. 2014). The best product in the Enting geti SME clusters based on consumer acceptance testing is SME of Wina Puri. The parameters that were the most influential included appearance and aroma because both of them had the highest score which means the panelists like them the most. According to Raljie and Jovanka (2009), the appearance of a product is the first sensory attribute that consumers pay attention to when choosing a product while aroma is a parameter that determines quality. A distinctive and attractive aroma can make food preferred by consumers (Mustofa and Agus, 2011).

\section{Laboratory Testing}

The determination of the first best formula was also carried out by laboratory tests. Laboratory tests are used to determine the quality content in food ingredients. Laboratory test results were analyzed by the MA method. Determination of MA was based on minimum density distance. SME with the best formula that has the minimum density distance is Kapal Layar; however, the results of the calculation of the IE and the calculation of MA produced the best formulas from different SMEs. Therefore, integration was carried out between 2 SMEs with the IE method. The highest product value produced was from the SME of Wina Puri which is the first best formula.

\section{Determination of the Best First Formula}

The IE and MA results were integrated to determine the first best formula. The IE results show that SME of Wina Puri was selected based on the highest product value. The result of MA indicates that Kapal Layar is the selected SME based on its lowest density distance. The two methods did not produce the same selected SMEs, so a re-effectiveness index is needed from the results of selected SMEs from both methods. The repeat IE results show that the SME of Wina Puri was chosen as the first best formula. 


\section{Improvement Process}

The improvement was based on the determination process hazard analysis and determination of the point of control. According to Marques et al. (2012), hazard analysis and determination of control points are the two main elements to minimize the occurrence of hazards and ensure food safety. The process improvement was carried out in the process of sugar cooking (caramelization) and reduction of the sesame composition. In the cooking process, 2 treatments were performed i.e. cooking with the temperatures of $75 \pm$ $2^{\circ} \mathrm{C}$ and of $85 \pm 2^{\circ} \mathrm{C}$. The caramelization process with the temperature of $70-75^{\circ} \mathrm{C}$ produced the best color according to consumers, where the color produced is golden brown (bright) (Dewi et al. 2014). The cooking temperature (caramelization) of $80-85^{\circ} \mathrm{C}$ is the optimal temperature that produces the best taste because there is an appropriate and not excessive caramelization reaction. In addition, these temperatures produce a greater degree of preference for color (Maharani et al. 2014).

This improvement was based on the results of laboratory tests which show that the test parameter that are not yet compliant with SNI is free fatty acids, so a reduction in cooking temperature is required. According to Harmita and Maksum(2008), free fatty acids are formed due to the process of oxidation and hydrolysis of enzymes during processing and storage. Free fatty acids will also increase along with the increased cooking temperature. The cooking temperature of Enting get $i$ before repair was $90-100^{\circ} \mathrm{C}$. Improvements were also made by reducing the sesame composition by $10 \%$. This was conducted because most panelists did not like the combination of sesame because it was given excessively so that it affected the taste of Enting geti (slightly bitter).

\section{Organoleptic Test Result After Improvement}

Determination of the best second formula was based on organoleptic test from SME of Wina Puri as the first best first formula. The improved process in making Enting geti is the process of cooking sugar (caramelization). The temperature of cooking sugar is generally around $90-100^{\circ} \mathrm{C}$. In addition to the improvement in the process, another improvement was also carried out with $10 \%$ sesame reduction. In this study, 2 treatments of cooking temperature were carried out i.e. at the temperatures of $75 \pm 2^{\circ} \mathrm{C}$ and of $85 \pm 2^{\circ} \mathrm{C}$. The organoleptic test was then carried out to check the color, taste, aroma, appearance, and texture parameters assessed using a Likert scale from 1 to 5 . This assessment was used to determine the level of preference among panelists for Enting geti that has been improved based on 2 different treatments. The results of the consumer acceptance test can be seen in Table 1 .

Based on Table 1, it can be seen that all parameters in treatment II were greater in value than treatment I, which showed that the panelis preferred the results of treatment II parameters. Enting geti treatment II has a bright brown color and tastes sweet, savory and not bitter because of the $10 \%$ sesame reduction while the aroma produced is distinctive but not too stinging, and the appearance produced is slightly hollow, and the texture is crispy (easily bitten but not soft and not easily broken). The results of the consumer acceptance test were then analyzed by the IE method which resulted in treatment II as the best treatment.

\section{Laboratory Test Result After Improvement}

Determination of the best second formula was also based on the laboratory test from SME of Wina Puri as the first best formula. The parameters used were the same as those for the first best formula. The best treatment results were obtained by analysis of MA, and the results of laboratory tests are shown in Table 2.

Based on Table 2, the results of laboratory tests on water content and free fatty acids were not assigned with SNI, while the yield of total plate count was appropriate, but its value had increased if compared to the condition before the refurbishment in both treatments. In water content, the value was still high because there was a definite dose from SMEs, where they only used an estimation system for water use so that they experienced obstacles determining the composition of water in process improvements. In free fatty acids, the water content was still high so that the process of oxidation and hydrolysis faster caused free fatty acids too high. In the total plate number, it was assigned with SNI although the value increased because the water content was still relatively high, making microbes easy to live and develop in Enting geti. The laboratory test results were analyzed by the multiple attribute methods which resulted in the best treatment. 
Table 1. The results of the consumer acceptance test after improvement

\begin{tabular}{|c|c|c|c|}
\hline \multirow[b]{2}{*}{ Parameters } & \multirow{2}{*}{$\begin{array}{c}\text { Before } \\
\text { (Temperature } \pm 90^{\circ} \mathrm{C} \\
\& \text { Wijen } 20 \% \text { ) }\end{array}$} & \multicolumn{2}{|c|}{ After (Temperature) } \\
\hline & & $\begin{array}{c}\mathrm{I} \\
\left(75 \pm 2^{\circ} \mathrm{C} \& \text { Wijen } 10 \%\right)\end{array}$ & $\begin{array}{c}\text { II } \\
\left(85 \pm 2^{\circ} \mathrm{C} \& \text { Wijen } 10 \%\right)\end{array}$ \\
\hline Color & 3,67 & 3,37 & $3,47^{*}$ \\
\hline Taste & 3,87 & 4,10 & $4,13^{*}$ \\
\hline Aroma & 3,67 & 3,63 & $3,83^{*}$ \\
\hline Appearance & 3,77 & 3,53 & $3,73^{*}$ \\
\hline Texture & 3,43 & 3,60 & $3,80^{*}$ \\
\hline
\end{tabular}

${ }^{*}$ ) the highest value in the treatment

Table 2. Laboratory test result after improvement for 2nd formula

\begin{tabular}{|c|c|c|c|c|}
\hline \multirow[b]{2}{*}{ Parameters } & \multirow{2}{*}{$\begin{array}{c}\text { Before } \\
\text { (Temperature } \pm 90^{\circ} \mathrm{C} \\
\text { \& Wijen } 20 \% \text { ) }\end{array}$} & \multicolumn{2}{|c|}{ After (Temperature) } & \multirow[b]{2}{*}{ SNI 01-4034-1996 } \\
\hline & & $\begin{array}{c}\mathrm{I} \\
\left(75 \pm 2^{\circ} \mathrm{C} \& \text { Wijen } 10 \%\right)\end{array}$ & $\begin{array}{c}\text { II } \\
\left(85 \pm 2^{\circ} \mathrm{C} \& \text { Wijen } 10 \%\right)\end{array}$ & \\
\hline Water content $(\%)$ & 2,23 & 7,25 & 4,94 & $<3,5$ \\
\hline Free fatty acids $(\%)$ & 1,71 & 2,59 & 2,86 & $<1$ \\
\hline Total place count (kol/gr) & 50 & 260 & 240 & $<500$ \\
\hline
\end{tabular}

\section{Determination of the Second Best Formula}

The results of IE were integrated with the results of MA to determine the second best formula. The value of IE shows that treatment II $\left(85 \pm 2^{\circ} \mathrm{C}\right.$ with $10 \%$ sesame reduction) was the chosen treatment based on the highest product value. The value of MA indicates that treatment II $\left(85 \pm 2^{\circ} \mathrm{C}\right.$ with $10 \%$ sesame reduction) was also the chosen treatment based on the lowest density distance. Both methods produced the same chosen treatment, so treatment II is the second best formula.

\section{Strategy for Improving the Quality of Enting geti Production Process Using the FAHP}

The strategy for quality improvement was prepared based on the conditions of the Enting geti SME clusters. In this strategy, the value of the consistency ratio (CR) is an important thing that needs attention. According to Anshori (2012), the standard value limit for CR consistency is $\mathrm{CR} \leq 0,10$ ( $\mathrm{CR}<10 \%)$. If the value of the consistency of the ratio produced does not meet the standards set, the assessment must be repeated. After obtaining the $\mathrm{CR}$ value, the assessment was changed into form of fuzzy using Triangular Fuzzy Number (TFN). According to Yang (2009), TFN is a decisionmaking process that approaches human thinking. TFN was chosen because it had a full membership value.
Furthermore, the analysis will produce priority on each alternative strategy which is displayed in the form of a hierarchy and can be seen in Figure 3 .

Analysis of determining the weight of each variable with the FAHP method was a basis for determining the priority of variables that need to be considered in improving the quality of the production process. In this study, there were 2 variables of raw materials and production, which were determined accordingly. The weight value of each variable can be seen in Table 3 . Based on Table 3, the priority variable can be seen in quality improvement efforts of Enting geti production process.

\section{Raw Materials}

The raw material weight of 0.306 was the second rank. The composition and quality of the raw materials used will affect taste, aroma, color, appearance and texture of the Enting geti. Therefore, the composition used in the production of Enting geti must be adjusted to the tastes preferred by consumers because the raw materials determine the final result. According to Giannini et al. (2000), the quality of raw materials greatly influences the quality of the final product. Better quality is also supported by the right production process. 


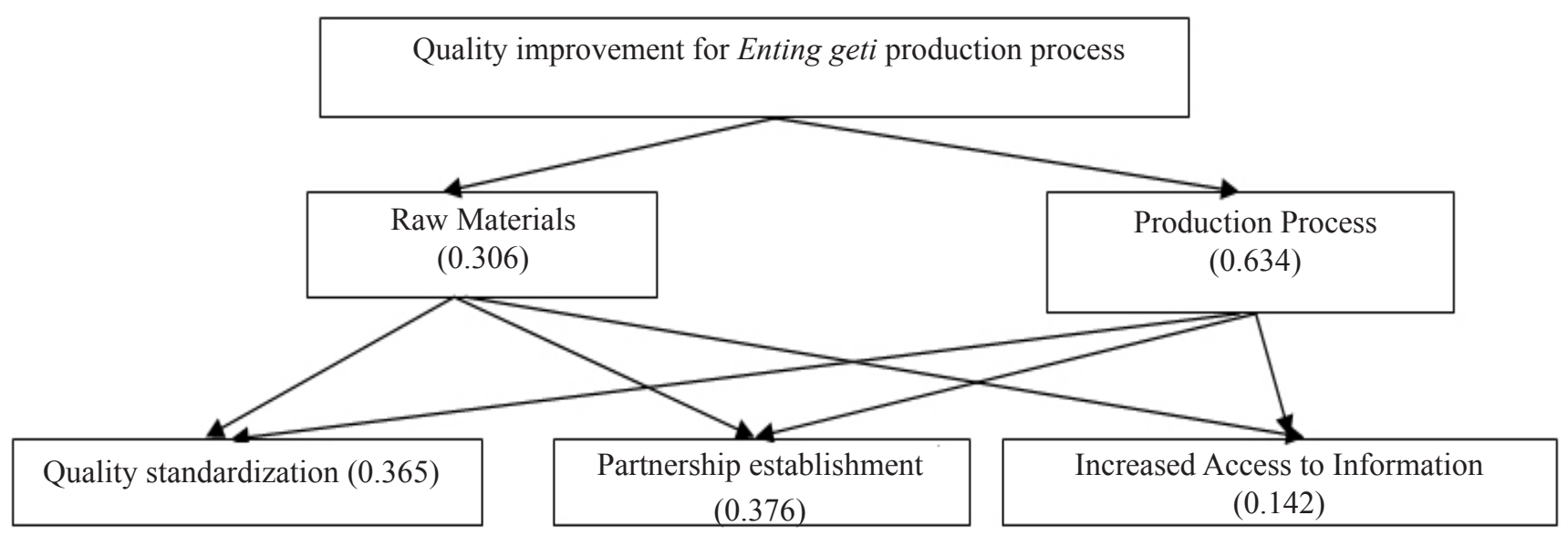

Figure 3. The Hierarchy structure formulation of production processfot quality improvement strategies

Table 3. The weight value of each variable

\begin{tabular}{lcc}
\hline Variable & Weight value & Rank \\
\hline Raw materials & 0.306 & 2 \\
Production process & 0.634 & 1 \\
\hline
\end{tabular}

The obstacle faced by SMEs is the supply of raw materials. The raw material prices tend to rise in certain seasons. This is because Enting geti demand increases so that the raw materials needed are also increased by increasing in raw material prices. According to Yunus (2016), the availability of raw material inventories is the optimal level in order to facilitate the production process at a minimum cost level. If inventory is not handled properly, the production process will be disrupted, resulting in producers losing their money.

\section{Production Process}

The variable of production process had a weight of 0.634 which was first ranked. The production process also influences the results of organoleptic products and the quality content of Enting geti. Before determining whether it needs to be repaired, CP first determined the extent of product safety if the process is not controlled. The process of improvement is needed to get better quality products. According to Mulyadi (2007), increasing product quality can reduce errors that occur in the production process, so cost reduction and schedule of product delivery time can be fulfilled. Errors in the production process can also be reduced by using quality raw materials. The good quality of raw materials will facilitate the production process and produce products of good quality (Czajkowska, 2015). The most influential process for quality of Enting geti is the caramelization process. In this process, the sugar is melted at a certain temperature until the sugar becomes caramel (thickens). The temperature and time used must be considered properly because it determines the final quality of Enting Geti. If there are errors in the production process, then this can reduce product quality, and operational costs will increase (Haris, 2005).

\section{Priority Analysis of Improvement Quality Strategy in Production Process}

This priority analysis is based on the strategy weight. The weighting of the biggest strategy shows the importance of strategy for improvement, while the variables are considered according to priority. The alternative value for each strategy is shown in Table 4. Based on the Table 4, the priority of alternative strategies for improving the quality of the production process of Enting geti can be seen.

\section{Quality standardization}

Quality standardization had a weight of 0.365 which is second ranked. The product must be at a certain level of quality because the product is made to meet consumer preference tastes (Sedayu et al. 2014). The main purpose of making standards is to protect end users (Machdar, 2018). This strategy is carried out with regular quality control. In controlling quality, there must be a system of reference used and desired quality standards such as SNI. In the production process, the control can be made of the material used, whether it is in accordance with the composition specified. In addition, cooking time and temperature must be controlled to produce uniform quality products. The standardization carried out by SMEs is limited to determine the shape and size 
of the beans used which is $8 \mathrm{~mm}$ in size with a slightly rounded shape. Standardization is also a measure of the standardization of the SME, which is needed as a whole. Meliala et al. (2014) suggested that the strategy of continuously improving the quality of the production process is a key factor in transforming the desires of each customer.

In raw materials, the standardization can be conducted by producing raw materials of the same size, shape and type. According to Halim et al. (2014), raw materials affect the organoleptic products produced so that raw materials must meet the standards. This quality control must also be based on desires and tastes of consumers. According to Julianti (2014), to always get good and competitive quality, quality improvement is needed continuously. To facilitate the quality control process of Enting geti, each evaluation should be stated in terms of situations, causes, and conditions. This can be used as a basis for making quality improvements to obtain standardized products (Pahan, 2007).

\section{Partnership establishment}

The partnership establishment obtained a weight of 0.375 which is the first rank. IT is needed to solve problems that are often experienced by SMEs, namely the delay in raw materials. It can guarantee the continuity of the production process. It can be a good cooperative relationship between SMEs and several fixed suppliers to obtain high quality of raw materials. The existence of this cooperative relationship with SMEs can obtain raw materials in accordance with the desired time. The price of the materials obtained is always fluctuated if SMEs have an impact on the price and quality of the product. Partnership establishment also supports the continuity of the production process. The suppliers are needed to avoid delays in raw materials and are able to expand business networks. Some of the advantages for SMEs when working with partnerships are the running of the production process becomes more efficient and production of quality products. The partnership pattern that can be applied to the Enting Geti SME clusters is a general trading pattern. General trading of mediumsized businesses and large businesses are part of the production chain (Abeng and Faisal, 2008). This strategy is also able to improve the quality of the final product because the use of good raw materials will produce high quality of end products (Jahanshahi, 2011). This is also supported by the right production process. According to Mulyadi (2007), business partnerships are built because of the inability of a business to meet customer needs. The business needs to grow and develop in the business environment globally.

Some of the best products for the production process are the efficiency and production of quality products. Strong partnerships are capable of producing long collaboration and better planning and joint problem solving efforts. According to Nugroho and Joni (2013), the existence of partnerships is important for business progress because it can overcome the obstacles faced such as technical, production and marketing problems. In cooperative relationships with partners, there is a partnership pattern, namely, a general trading pattern. General trading of medium-sized businesses and large businesses are part of the production chain (Abeng and Faisal, 2008).

\section{Increased Access to Information}

Increased access to information gained a weight of 0.142 as the third rank. Increased access to information can be carried out by conducting market surveys or market research. There is market research to find out consumer tastes towards products (Famiyeh, 2017). An effort that can be made in gathering information related to consumer tastes is by making SMEs as important as possible for students, and students and the public. In addition, conducting market research has also been done by conducting market research such as requesting products from consumers on products and services at sales outlets and resellers, as well as participating in product exhibitions. According to Enterprise (2010), market research attempts to collect information in a systematic, objective and planned manner about consumers or markets, where accurate and credible information is needed.

Table 4. The weight value of each strategy

\begin{tabular}{lcc}
\hline Alternatif & Weight value & Rank \\
\hline Quality standardization & 0.365 & 2 \\
Partnership establishment & 0.375 & 1 \\
Increased Access to & 0.142 & 3 \\
Information & & \\
\hline
\end{tabular}


Increased access to information can also be used for information related to technology that can be applied. The use of technology is very useful to meet the needs of the business process in the process (Novera, 2017). In addition, the use of appropriate technology can be streamlined with production time and increase the profitability of SMEs. According to Pradana (2009), the use of appropriate technology in the production process can increase competitiveness through market expansion and increased production capacity.

\section{Managerial Implications}

Based on quality improvements through the consumer and laboratory testing and formulation of quality management, a number of managerial implementations can be carried out including 1) Quality Standardization, starting from controlling overall quality. In raw materials, it can be done by sorting before using them so that the shape and type of raw material is not much different. In the production process, it can be done with the CP approach and then compare it with SNI. 2) Partnership establishment can be applied to apply partnership patterns i.e. general trading patterns conducted by building partnerships with several fixed suppliers. In addition, improvements to information flow are also needed between producers and suppliers. 3) Increased access to information can be done by conducting market research. Increasing access to information can also be done by making SMEs as a means of education for students, students and the public. In addition, SMEs can access information on technology that is appropriate if applied to SMEs.

\section{CONCLUSIONS AND RECOMMENDATIONS}

\section{Conclusions}

The results of the best first formula based on consumer acceptance. The results of consumer acceptance tests were color (3.67), taste (3.87), aroma (3.67), appearance (3.77), and texture (3.43). In the results of laboratory tests, the indicator that has not been complied with SNI is free fatty acids. After the process improvement, the best second formula is treatment II (temperature $85 \pm 2^{\circ} \mathrm{C}$ ) with the results of the consumer acceptance test namely color (3.47), taste (4.13), aroma (3.83), appearance (3.73), and texture (3.80) to be followed up by the SMEs Enting geti cluster. The laboratory results showed that the water content and free fatty acids were not suitable, but the total plate number had fulfilled SNI.

The strategy for improving the quality of the Enting geti production process was obtained by the highest weight, namely, the production process variable (0.635). Alternative strategies obtained include quality standardization, partnershipestablishmentandincreased access to information. The alternative strategy chosen is to establish a partnership (0.376).

\section{Recommendations}

Suggestions that can be given are related to quality improvement through the consumer acceptance testing and formulation of strategies for improving the quality of production processes are as follows: 1) Following up on the results of the second best formula improvement in the production process to get the best quality based on consumer acceptance and laboratory testing in accordance with SNI, 2) Evaluation must be conducted regularly by SMEs to find out weaknesses and improve quality so that they are in accordance with SNI and consumer tastes. 3) Coordination between SMEs and suppliers must be improved to maintain smooth production and minimize scarcity of raw materials. The existence of raw material inventories is an optimal level in order to facilitate the production process at a minimum cost level. If inventory is not handled properly, the production process will be disrupted, resulting in producers losing money, and 4) Openness with outsiders to add information to support business improvement in all aspects. It is recommended that the next research use the real formula of SMEs that are the results of the process of improvement which are better and in accordance with SNI.

\section{REFERENCES}

Abeng T, Faisal S. 2008. Reformasi BUMN Dalam Perspektif Krisis Ekonomi. Jakarta: PT Gramedia Pustaka Utama.

Anshori Y. 2012. Pendekatan triangular fuzzy number dalam metode analytical hierarchy process. Jurnal Ilmiah Forensik 2(1): 126-135.

Astuti E. 2013. Perilaku konsumtif dalam membeli barang pada ibu rumah tangga di Kota Samarinda. Jurnal Psikologi 1(2): 148-156. 
Budiarto R et al. 2015. Pengembangan UMKM Antara Konseptual dan Pengalaman Praktis. Yogyakarta: Gajah Mada University Press.

Czajkowska, Kadublek M. 2015.Management of factors affecting quality of processes in construction interprise. Journal of Management 11(1): 2838.

Dewi K et al. 2014. Study on consumer acceptance of "koteja" product with additional efficiencious material. Journal of Technology and Agroindustrial Indonesia 6 (2): 49-53.

Dianawati D, Fasich, Umi A. 2008. Hubungan persepsi terhadap iklan di televisi dengan perilaku swamedikasi pelajar SMU Negeri di Surabaya. Majalah Farmasi Airlangga 6 (1): 10-15.

Enterprise J. 2010. Microsoft Office 2010 untuk Dunia Bisnis. Jakarta: PT Elex Media Komputindo.

Evans JR. 2013. Insights on the future of quality management research. Quality Management Journal 20(1): 48-55. https://doi.org/10.1080/1 0686967.2013.11918091.

Famiyeh S. 2017. Service quality, customer satisfaction and loyalty in automobile maintenance services: evidence from a developing country. Journal of Quality in Maintenance Engineering 24(3): 262-279. https://doi.org/10.1108/JQME-102016-0056.

Gaspersz V. 2005. Production Planning and Inventory Control Berdasarkan Pendekatan Sistem Terintegrasi MRP II dan JIT Menuju Manufacturing 21. Jakarta: Gramedia.

Giannini D et al. 2001. Influence of rawmaterial quality on quality of iced and frozen white fish products. Journal OfFood Quality 24 (1): 527-538. https:// doi.org/10.1111/j.1745-4557.2001.tb00628.x.

Hadiati S. 2016. Peran struktur pasar dan daya saing dalam meningkatkan kinerja umkmm kerajinan keramik. Jurnal Ekonomi dan Keuangan 20(3): 367-387. https://doi.org/10.24034/j25485024. y2016.v20.i3.1839.

Halim P et al. 2014. The influence of product quality, brand image, and quality of swrvice to customer trust and implication on customer loyalty (survey on customer brand sharp electronics product at the south kalimantan province).European Journal of Business and Management 6(29): 2222-2839.

Haris A. 2005. 7 Pilar Perusahaan Unggul. Jakarta: PT Gramedia Pustaka Utama.

Harmita, Maksum R. 2008. Buku Ajar: Analisis Hayati.
Jakarta: Penerbit Buku Kedokteran EGC.

Idmayanti R. 2014. Sistem pendukung keputusan penentuan penerimaan beasiswa BBM (bantuan belajar mahasiswa) Pada Politeknik Negeri Padang menggunakan metode fuzzy multiple attribute decision making. Jurnal Teknologi Informasi \& Pendidikan 7(01): 18-28.

Jahanshahi A. 2011. Study the effect of c u s t o m e r service and product quality on customer satisfaction and loyalty. International Journal of Humanities And Social Science 1(7):253-260.

Julianti S. 2014. The art of packaging. Jakarta: PT Gramedia Pustaka Utama.

Kurniasanti SA, Sumarwan U, Kurniawan BPY. 2014. Analisis dan model strategi peningkatan daya saing produk edamame beku. Jurnal Manajemen dan Agribisnis 11(3): 154-163.

Lupo T. 2013. Strategic analyisis of transit service quality using fuzzy AHP methodology. Journal Of European Transport 5(53): 1825-3997.

MachdarI.2018. PengantarPengendalian Pencemaran. Yogyakarta: Deepublish.

Maharani D et al. 2014.Pengaruh penambahan natrium metasulfit dan suhu pemasakan dengan menggunakan teknologi vakum terhadap kualitas gula merah tebu.Jurnal Agritech 34 (04):365-372. https://doi.org/10.22146/ agritech. 9430 .

Marques N et al. 2012. Implementation of hazard analysis critical control points (HACCP) in a SME: case study of a bakery. Polish Journal of Food and Nutrition Sciences 62(4): 215-227. https://doi.org/10.2478/v10222-012-0057-5.

Meliala AS, Nazaruddin M, Rahmi MS. 2014. Strategi peningkatan daya saing usaha kecil dan menengah (UKM) berbasis kaizen. Jurnal Optimasi Sistem Industri 13(2): 641-664. https:// doi.org/10.25077/josi.v13.n2.p641-664.2014.

Molnar P. 2008. Food quality indices. Journal of Food Quality 2(3): 1-11.

Mulyadi A et al. 2014. Karakteristik organoleptik produk mie kering ubi jalar kuning (ipomoe batatas) (kajian penambahantelur dan $\mathrm{CMC}$ ). Jurnal Teknologi Pertanian 15(01):25-36.

Mulyadi. 2007. Sistem Perencanaan dan Pengendalian Manajemen. Jakarta: Salemba Empat.

Mustaniroh A, Kristianti RM, Maligan JM. 2017. Determination of the best formula apple cider beverages in the production process through consumer's acceptance and laboratory's 
integration (case study in apple cider beverages cluster in Batu city, East Java). Research Journal of Applied Sciences, Engineering, and Technology 14(10): 380-385. https://doi. org/10.19026/rjaset.14.5130.

Mustofa K, Suyanto A. 2011. Kadar kalsium, daya kembang, dan sifat organoleptik kerupuk onggok singkong dengan variasi penambahan tepung cangkang rajungan (portunus pelagicus). Jurnal Pangan dan Gizi 2 (3): 1-14

Nayantakaningtyas JS, Daryanto HK. 2012. Daya saing strategi pengembangan minyak sawit di indonesia. Jurnal Manajemen dan Agribisnis. 9(3): 194-201.

Norhikmah, Rumini, Henderi. 2013.Metode Fuzzy AHP dalam penerapan sistem pendukung keputusan. Seminar Nasional Teknologi Informasi Dan Multimedia.Yogyakarta.STMIK AMIKOM. pp. 31-38.

Novera R. 2017. Higiene Industri. Yogyakarta: Deepublish.

Nugroho Y, Joni K. 2015. Aplikasi kulit manggis (garcia mangostanal.) sebagai $\mathrm{s} \mathrm{u} \mathrm{m} \mathrm{b}$ e $\mathrm{r}$ antioksidan pada es krim. Jurnal Pangan Dan Agroindustri 3 (4): 1263-1271.

Nurani, S. dan S. Susilo. 2014. Pemanfaatan tepung kimpul (xanthosomasagittifolium)s e b a $\mathrm{g}$ a $\mathrm{i}$ bahan baku cookies (kajian proporsi tepung dan penambahan margarin). Jurnal Pangan Dan Agroindustri 2(2): 50-58.

Ofafa G. 2013. Enhancing market access in Kenyan SMEs using ICT. Global Business and Economics Research Journal 2 (9): 29-46.

Pahan I. 2007. Panduan Lengkap Kelapa Sawit. Jakarta. Penebar Swadaya.

Pradana R. 2009. Sains \& Teknologi 2. Jakarta: PT Gramedia Pustaka Utama.

Raljie J, Petronijevie J. 2009. Sensory properties and color measurement of dietary chocolates with different compositions during storage for up to 360 days. Journal of Sensors 2009(9): 19962016. https://doi.org/10.3390/s90301996.

Ruauw E. 2011. Pengendalian persediaan bahan baku (Contoh pengendalian pada usaha Grenda Bakery Lianli, Manado). Jurnal ASE 7(1): $1-11$.
Sahin B, Young L. 2017. Shipping technology selection for dynamic capability based on improved gaussian fuzzy AHP Model. Journal of Ocean Engineering 136 (1): 233-242. https://doi. org/10.1016/j.oceaneng.2017.03.032.

Sedayu A, Harnen S, Suyanto A, Wahyudi A. 2014. Standar pelayanan minimal terminal bus tipe A. Malang: UB Press.

Setyadi I et al. 2012. Strategi pengembangan ekowisata di Taman Nasional Sebangau Kalimantan Tengah. Jurnal Manajemen dan Agribisnis 9(1): $1-12$.

Sriwana I. 2014. Identifikasi risiko rantai pasok agroindustri kakao menggunakan Fuzzy AHP Jurnal Inovasi TM. 10 (1): 10-18.

Stefanie R. 2013. Respon pengunjung terhadap media brosur Jatim Park 2. Jurnal E-Komunikasi Universitas Kristen Petra Surabaya 1 (3): 309-320.

Suradi K. 2007. Tingkat kesukaan bakso dari berbagai jenis daging melalui beberapa pendekatan statistik (the hedonic scaling of $\mathrm{m}$ e a t b a 11 from various kind of meat on several statistic approached). Jurnal Ilmu Ternak 7(1): 52-57.

Wang Y, Chin KS. 2011. Fuzzy analytic h i e r a r c hy process: a logarithmic fuzzy preference programming methodology. International Journal of Approximate Reasoning 52 (4): 541553. https://doi.org/10.1016/j.ijar.2010.12.004.

Wibowo DH, Zainul A, Sunarti. 2015. Analisis strategi pemasaran untuk meningkatkan daya saing UMKM (Studi Pada Batik Diajeng Solo). Jurnal Administrasi Bisnis 29(1):59-66.

Widyastutik, Arianti RK. 2013. Strategi kebijakan mutu dan standar produk ekspor dalam meningkatka daya saing (studi kasus produk biji kakao). Jurnal Manajemen dan Agribisnis 10(2): 98-108.

Yang J. 2009. Integrative performance evaluation for supply chain system based on logarithm triangular fuzzy number AHP method. Journal of Kybernetes 38(10): 1760-1770.

Yunus E. 2016. Manajamen Strategis. Yogyakarta. ANDI.

Yuyun A. 2010. 38 Inspirasi Usaha Makanan Minuman untuk Home Industri. Jakarta: PT Agromedia Pustaka.

Zeleny M. 1982. Multiple Criteria Decision Making. New York: McGraw-Hill. 